Article

\title{
New Coumarins and Anti-Inflammatory Constituents from the Fruits of Cnidium monnieri
}

\author{
Tzong-Huei Lee ${ }^{1, \dagger}$, Yuan-Chih Chen ${ }^{2, \dagger}$, Tsong-Long Hwang ${ }^{3}$, Chih-Wen Shu ${ }^{4}$, \\ Ping-Jyun Sung ${ }^{5}$, Yun-Ping Lim ${ }^{6}$, Wen-Lung Kuo ${ }^{7}$ and Jih-Jung Chen ${ }^{2, *}$
}

1 Graduate Institute of Pharmacognosy, Taipei Medical University, Taipei 110, Taiwan; E-Mail: thlee@tmu.edu.tw

2 Department of Pharmacy \& Graduate Institute of Pharmaceutical Technology, Tajen University, Pingtung 907, Taiwan; E-Mail: cute88883333@yahoo.com.tw

3 Graduate Institute of Natural Products, College of Medicine, Chang Gung University, Taoyuan 333, Taiwan; E-Mail: htl@mail.cgu.edu.tw

4 Department of Medical Education and Research, Kaohsiung Veterans General Hospital, Kaohsiung 813, Taiwan; E-Mail: cwshu@vghks.gov.tw

5 National Museum of Marine Biology and Aquarium, Pingtung 944, Taiwan; E-Mail: pjsung@nmmba.gov.tw

6 School of Pharmacy, College of Pharmacy, China Medical University, Taichung 404, Taiwan; E-Mail: limyp@mail2000.com.tw

7 Chung-Jen College of Nursing, Health Science and Management, Chiayi 600, Taiwan; E-Mail:m049@cjc.edu.tw

$\dagger$ These authors contributed equally to this work.

* Author to whom correspondence should be addressed; E-Mail: jjchen@tajen.edu.tw; Tel.: +886-8-7624-002 (ext. 2827); Fax: +886-8-7624-002 (ext. 5121).

Received: 3 March 2014; in revised form: 7 May 2014 / Accepted: 13 May 2014 / Published: 28 May 2014

\begin{abstract}
The fruit of Cnidium monnieri is commercially used as healthcare products for the improvement of impotence and skin diseases. Three new coumarins, 3'-O-methylmurraol (1), rel-(1'S,2'S)-1'-O-methylphlojodicarpin (2), and (1'S,2'S)-1'-O-methylvaginol (3), have been isolated from the fruits of $C$. monnieri, together with 14 known compounds (4-17). The structures of these new compounds were determined through spectroscopic and MS analyses. Compounds 1, 4-12, and 14-17 exhibited inhibition ( IC $_{50} \leq 7.31 \mu \mathrm{g} / \mathrm{mL}$ ) of superoxide anion generation by human neutrophils in response to formyl-L-methionyl-L-
\end{abstract}


leucyl-L-phenylalanine/cytochalasin B (fMLP/CB). Compounds 7, 9-11, 15, and 17 inhibited fMLP/CB-induced elastase release with $\mathrm{IC}_{50}$ values $\leq 7.83 \mu \mathrm{g} / \mathrm{mL}$. This investigation reveals that bioactive isolates (especially $6,7, \mathbf{1 4}$, and 17) could be further developed as potential candidates for the treatment or prevention of various inflammatory diseases.

Keywords: Cnidium monnieri; umbelliferae; coumarins; structure elucidation; anti-inflammatory activity

\section{Introduction}

Cnidium monnieri (L.) Cusson (Umbelliferae) is an annual herb distributed in China, India, Russia, Korea, Mongolia, Vietnam, Europe, and North America [1,2]. Chromones [3,4], coumarins [5-9], benzofurans [10], and monoterpenoids [11], and their derivatives were isolated from this plant in previous studies. Many of these compounds were found to exhibit antidermatophytic [9], anti-scratching [5], and cytotoxic [8] activities. Granule proteases (e.g., elastase, cathepsin G, and proteinase-3) and reactive oxygen species (ROS) (e.g., superoxide anion $\left(\mathrm{O}_{2}{ }^{-}\right)$and hydrogen peroxide) produced by human neutrophils are involved in the pathogenesis of a variety of inflammatory diseases.

In our studies on the anti-inflammatory constituents of Formosan plants, many species have been screened for in vitro inhibitory activity on neutrophil pro-inflammatory responses, and C. monnieri has been found to be an active species. The $\mathrm{MeOH}$ extract of the fruits of $C$. monnieri showed potent inhibitory effects on superoxide anion generation and elastase release by human neutrophils in response to formyl-L-methionyl-L-leucyl-L-phenylalanine/cytochalasin $\mathrm{B}$ (fMLP/CB). Figure 1 illustrates the structures of three new coumarins, 3'-O-methylmurraol (1), rel-(1'S,2'S)-1'-Omethylphlojodicarpin (2), and (1'S,2'S)-1'-O-methylvaginol (3). Fourteen known compounds (4-17), have been isolated and identified from the fruits of $C$. monnieri and their structures are depicted in Figure 2.

This paper describes the structural elucidation of the compounds numbered $\mathbf{1}$ through $\mathbf{3}$, and the inhibitory activities of all isolates on superoxide generation and elastase release by neutrophils.

Figure 1. The chemical structures of new compounds 1-3 isolated from C. monnieri.

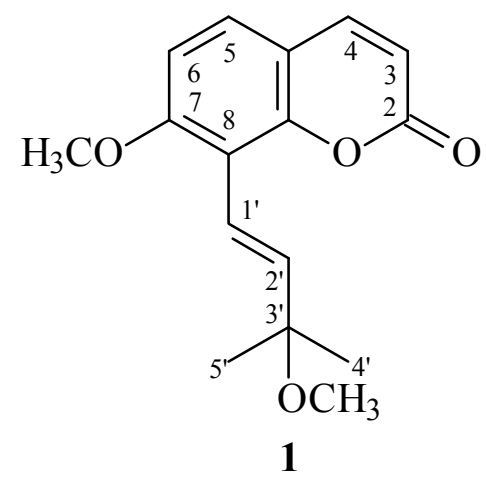

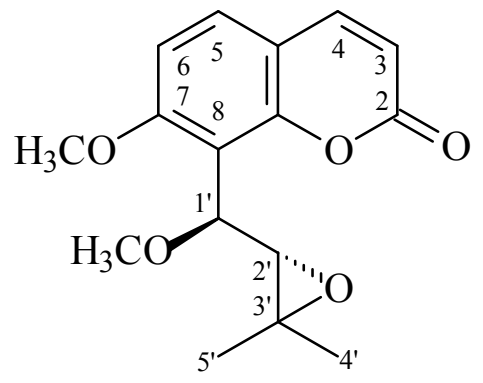

2

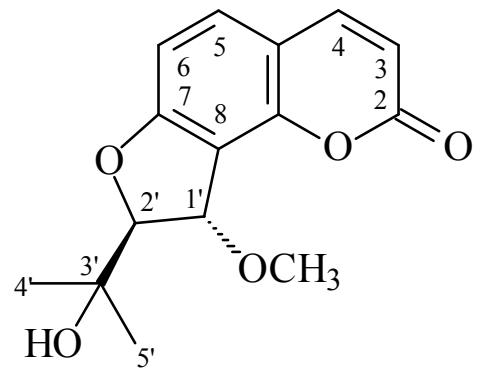

3 
Figure 2. The chemical structures of known compounds 4-17 isolated from $C$. monnieri.<smiles>[R]OC(C)(C)/C=C/c1c(OC)ccc2ccc(=O)oc12</smiles>

$4 \mathrm{R}=\mathrm{H}$

$5 \mathrm{R}=\mathrm{OH}$<smiles>COc1ccc2ccc(=O)oc2c1C[C@@H](O)C(C)(C)O</smiles>

10<smiles>CC(C)=CCOc1c2occc2cc2ccc(=O)oc12</smiles>

14<smiles>[R20]c1ccc2ccc(=O)oc2c1CC=C(C)C</smiles>

$6 \mathrm{R}=\mathrm{OCH}_{3}$

$7 \mathrm{R}=\mathrm{OH}$<smiles>C=C(C)[C@H](O)Cc1c(O)ccc2ccc(=O)oc12</smiles>

11<smiles>[R]C(Cc1c(OC)ccc2ccc(=O)oc12)C(=C)C</smiles>

$8 \mathrm{R}=\mathrm{H}$

$9 \mathrm{R}=\mathrm{OH}$<smiles>[R2]c1c2occc2cc2ccc(=O)oc12</smiles>

$12 \mathrm{R}=\mathrm{CH}_{3}$

$13 \mathrm{R}=\mathrm{H}$<smiles>[R]c1c2occc2c(OC)c2ccc(=O)oc12</smiles>

$15 \mathrm{R}=\mathrm{H}$

$16 \mathrm{R}=\mathrm{OCH}_{3}$

17

\section{Results}

Chromatographic purification of the EtOAc-soluble fraction of a $\mathrm{MeOH}$ extract of fruits of C. monnieri on a silica gel column and preparative thin-layer chromatography (TLC) afforded three new (1-3) and 14 known compounds (4-17).

3'-O-Methylmurraol (1) was isolated as colorless prism with molecular formula $\mathrm{C}_{16} \mathrm{H}_{18} \mathrm{O}_{4}$ as determined by positive-ion HRESIMS, showing an $[\mathrm{M}+\mathrm{Na}]^{+}$ion at $\mathrm{m} / z 297.1105$ (calcd for $\mathrm{C}_{16} \mathrm{H}_{18} \mathrm{O}_{4} \mathrm{Na}$, 297.1103). The presence of a carbonyl group was revealed by a band at $1727 \mathrm{~cm}^{-1}$ in the IR spectrum, and was confirmed by the resonance at $\delta 160.9$ in the ${ }^{13} \mathrm{C}$-NMR spectrum. The ${ }^{1} \mathrm{H}-\mathrm{NMR}$ spectrum of 1 showed the presence of an $(E)$-3-methoxy-3-methylbut-1-enyl group [ $\delta 1.42(6 \mathrm{H}, \mathrm{s}$, H-4', H-5'), 3.28 (3H, s, OMe-3'), 6.79 (1H, d, $J=16.0$ Hz, H-2'), 6.83 (1H, d, $J=16.0$ Hz, H-1')], a methoxy group $[\delta 3.95(3 \mathrm{H}, \mathrm{s}, \mathrm{OMe}-7)]$, an $\mathrm{AB}$ spin system $[\delta 6.88(1 \mathrm{H}, \mathrm{d}, J=9.0 \mathrm{~Hz}, \mathrm{H}-6)$ and 
$7.31(1 \mathrm{H}, \mathrm{d}, J=9.0 \mathrm{~Hz}, \mathrm{H}-5)]$, and the typical H-3 and $\mathrm{H}-4$ protons of the coumarin nucleus $[\delta 6.27$, 7.63 (each $1 \mathrm{H}$, each d, $J=9.5 \mathrm{~Hz}, \mathrm{H}-3$ and H-4)]. The ${ }^{1} \mathrm{H}-\mathrm{NMR}$ data of 1 was similar to those of murraol [12,13], except that the 3'-methoxy group [ $\delta 3.28(3 \mathrm{H}, \mathrm{s})]$ of $\mathbf{1}$ replaced the 3'-hydroxy group of murraol. This was supported by HMBC correlation observed between OMe-3' $(\delta 3.28)$ and C-3' $\left(\delta\right.$ 75.9), and by NOESY correlations observed between OMe-3' $\left(\delta\right.$ 3.28) and $\mathrm{H}-4^{\prime} / \mathrm{H}-5^{\prime}\left(\begin{array}{l}\delta \\ 1.42\end{array}\right)$. The full assignment of ${ }^{1} \mathrm{H}$ - and ${ }^{13} \mathrm{C}-\mathrm{NMR}$ resonances was confirmed by ${ }^{1} \mathrm{H}-{ }^{1} \mathrm{H}$ COSY, NOESY (Figure 3), DEPT, HSQC, and HMBC (Figure 3) techniques. According to the evidence above, the structure of 1 was elucidated as (E)-7-methoxy-8-(3-methoxy-3-methylbut-1-enyl)-2H-chromen-2-one, named 3'-O-methylmurraol.

Figure 3. Key NOESY (a) and HMBC (b) correlations of 1.

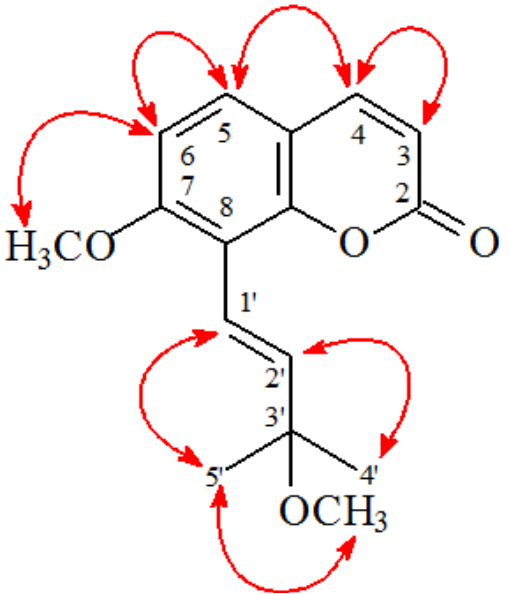

(a)

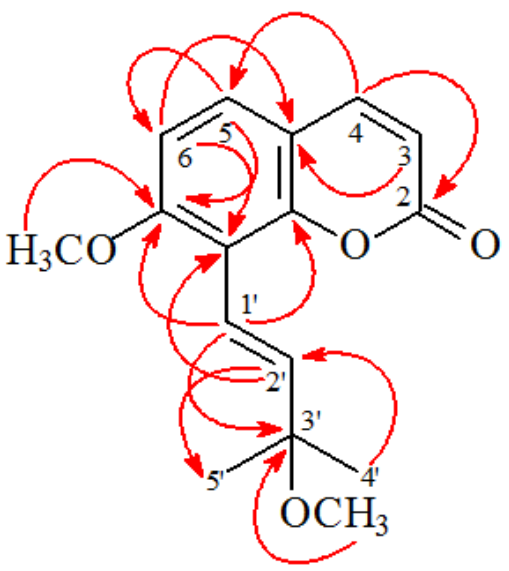

(b)

rel-(1'S,2'S)-1'-O-Methylphlojodicarpin (2) was obtained as optically active, colorless needles $\left([\alpha]_{\mathrm{D}}{ }^{25}=-28.4\right)$. Its molecular formula, $\mathrm{C}_{16} \mathrm{H}_{18} \mathrm{O}_{5}$, was determined on the basis of the positive HRESIMS at $m / z 313.1050[\mathrm{M}+\mathrm{Na}]^{+}$(calcd 313.1052) and supported by the ${ }^{1} \mathrm{H}-,{ }^{13} \mathrm{C}$-, and DEPT NMR data. The presence of a carbonyl group was revealed by a band at $1733 \mathrm{~cm}^{-1}$ in the IR spectrum, and was confirmed by the resonance at $\delta 160.2$ in the ${ }^{13} \mathrm{C}-\mathrm{NMR}$ spectrum. The ${ }^{1} \mathrm{H}-\mathrm{NMR}$ data of 2 were similar to phlojodicarpin [14], except that the 1'-methoxy group [ $\delta 3.48(3 \mathrm{H}, \mathrm{s})]$ of 2 replaced OH-1' of phlojodicarpin [14]. This was supported by the NOESY correlations between OMe-1' $(\delta 3.48)$ and H-1' $(\delta 4.84)$, and by the HMBC correlation between OMe-1' $(\delta 3.48)$ and C-1' $(\delta$ 75.1) of 2. In addition, the rel-(1'S,2'S)-configuration of 2 was established by the following evidences: (a) The larger coupling constant $(J=7.0 \mathrm{~Hz})$ between $\mathrm{H}_{\alpha^{-}} 1^{\prime}$ and $\mathrm{H}_{\beta^{-}} 2^{\prime}$ of 2 was similar to that $(J=6.9 \mathrm{~Hz})$ of hydroxyosthole epoxide with rel-(1'S,2'S)-configuration [15], and different from that $(J=3.0 \mathrm{~Hz})$ of phlojodicarpin [14]; (b) The NOESY correlations were observed between $\mathrm{H}_{\alpha}-1^{\prime} / \mathrm{Me}_{\alpha}-3^{\prime}$ and $\mathrm{H}-2^{\prime} / \mathrm{Me}_{\beta}-3^{\prime}$ (Figure 3); (c) Compound 2 showed a laevorotatory optical activity with $[\alpha]_{\mathrm{D}}{ }^{25}=-28.4$ as in the cases of hydroxyosthole epoxide $\left([\alpha]_{\mathrm{D}}{ }^{25}=-26.7\right)$ [15]. Thus, the structure of 2 was elucidated as rel-(1'S,2'S)-1'-O-methylphlojodicarpin. This structures was confirmed by the ${ }^{1} \mathrm{H}-{ }^{1} \mathrm{H}$ COSY, NOESY (Figure 4), DEPT, HSQC, and HMBC techniques (Figure 4). 
Figure 4. Key NOESY (a) and HMBC (b) correlations of 2.

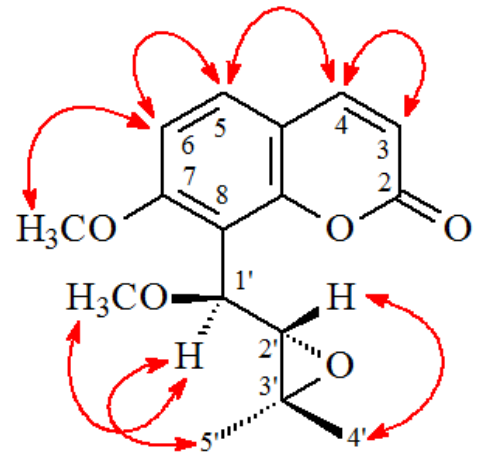

(a)

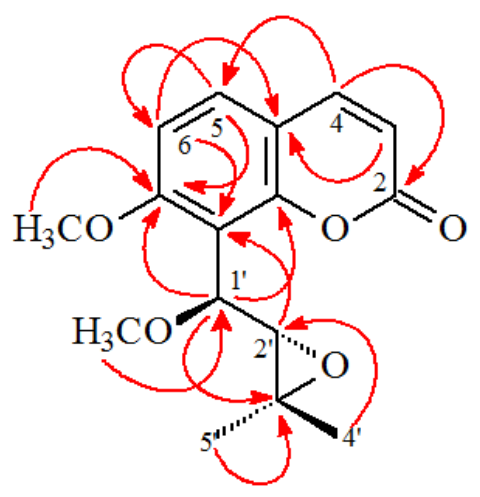

(b)

(1'S,2'S)-1'-O-Methylvaginol (3) was isolated as an colorless prism $\left([\alpha]_{\mathrm{D}}{ }^{25}+120.4\right)$. The molecular formula $\mathrm{C}_{15} \mathrm{H}_{16} \mathrm{O}_{5}$ was deduced from a sodium adduct ion at $\mathrm{m} / z 299.0892[\mathrm{M}+\mathrm{Na}]^{+}($calcd 299.0895$)$ in the HRESI mass spectrum. The presence of a carbonyl group was revealed by the band at $1727 \mathrm{~cm}^{-1}$ in the IR spectrum. The ${ }^{1} \mathrm{H}$ - and ${ }^{13} \mathrm{C}-\mathrm{NMR}$ data of $\mathbf{3}$ were similar to those of vaginol [16], except that the 1'-methoxy group $\left[\delta_{\mathrm{H}} 3.65\left(3 \mathrm{H}, \mathrm{s}, \mathrm{OMe}-1^{\prime}\right) ; \delta_{\mathrm{C}} 57.8\left(\mathrm{OMe}-1^{\prime}\right)\right]$ of 3 replaced 1'-hydroxy group of vaginol. This was supported by the HMBC correlation between OMe-1' $(\delta 3.65)$ and $\mathrm{C}-1^{\prime}(\delta$ 79.4) and by the NOESY correlations between OMe-1' $(\delta$ 3.65) and both H-1' $(\delta$ 5.23) and H-2' $(\delta$ 4.53). In addition, the 1'S,2'S-configuration of $\mathbf{3}$ was established by the following evidences: (a) The small coupling constant $(J=3.0 \mathrm{~Hz})$ between $\mathrm{H}_{\beta}-1^{\prime}$ and $\mathrm{H}_{\alpha}-2^{\prime}$ of 3 was similar to that $(J=3.6 \mathrm{~Hz})$ of vaginol with 1 'S,2'S-configuration [16], and different from that $(J=5.5 \mathrm{~Hz})$ of vaginidiol with $1^{\prime} R, 2^{\prime} S$-configuration [16]; (b) The NOESY correlations were observed between $\mathrm{OMe}_{\alpha}-1^{\prime} / \mathrm{H}_{\alpha}-2^{\prime}$, $\mathrm{H}_{\beta^{-}} 1^{\prime} / \mathrm{H}-4^{\prime}$, and $\mathrm{H}_{\beta^{-}} 1^{\prime} / \mathrm{H}-5^{\prime}$; (c) Compound 3 showed a dextrorotatory optical activity with $[\alpha]_{\mathrm{D}}{ }^{25}=+120.4$, which was similar to vaginol $\left([\alpha]_{\mathrm{D}}{ }^{20}=+119^{\circ}\right)$ with $1^{\prime} S, 2^{\prime} S$-configuration [16], and different from vaginidiol $\left([\alpha]_{\mathrm{D}}{ }^{20}=+223^{\circ}\right)$ with $1^{\prime} R, 2^{\prime} S$-configuration [16]. According to the above data, the structure of 3 was elucidated as $\left(1^{\prime} S, 2 ' S\right)-1^{\prime}-O$-methylvaginol. This was supported by ${ }^{1} \mathrm{H}-{ }^{1} \mathrm{H}$ COSY and NOESY (Figure 5) experiments, and ${ }^{13} \mathrm{C}-\mathrm{NMR}$ assignments were confirmed by DEPT, HSQC, and HMBC (Figure 5) techniques.

Figure 5. Key NOESY (a) and HMBC (b) correlations of 3.

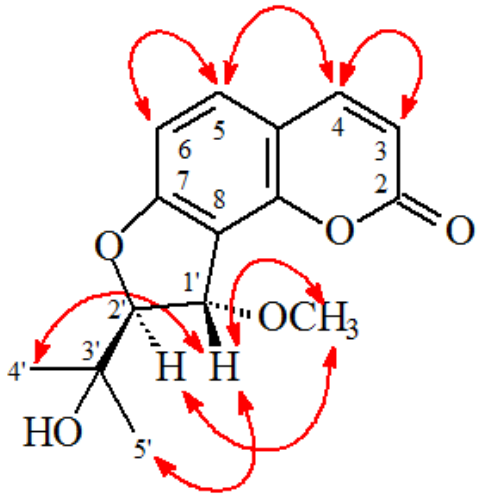

(a)

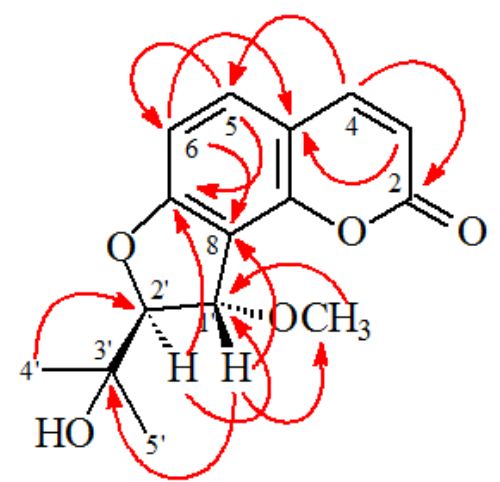

(b) 
The known isolates were readily identified by a comparison of physical and spectroscopic data (UV, IR, ${ }^{1} \mathrm{H}-\mathrm{NMR},[\alpha]_{\mathrm{D}}$, and MS) with corresponding authentic samples or literature values, and this included 13 coumarins, murraol (4) [12,13], peroxymurraol (5) [12,13], osthol (6) [12,17], osthenol (7) [18], auraptenol (8) [6,19], peroxyauraptenol (9) [12] [13], meranzin hydrate (10) [12,13], demethylauraptenol (11) [20], xanthotoxin (12) [17,21], xanthotoxol (13) [17], imperatorin (14) [17], bergapten (15) [17,21], and isopimpinellin (16) [17,21], and a chromone, cnidimol A (17) [22].

Table 1. Inhibitory effects of compounds 1-17 from the fruits of $C$. monnieri on superoxide radical anion generation and elastase release by human neutrophils in response to fMet-Leu-Phe/cytochalasin $\mathrm{B}^{\text {a }}$.

\begin{tabular}{|c|c|c|}
\hline \multirow{2}{*}{ Compounds } & Superoxide Anion & Elastase \\
\hline & \multicolumn{2}{|c|}{$\mathrm{IC}_{50}[\mu \mathrm{g} / \mathrm{mL}]^{\mathrm{b}}$ or $(\operatorname{Inh} \%)^{\mathrm{c}}$} \\
\hline 3'-O-Methylmurraol (1) & $6.24 \pm 0.50^{\mathrm{g}}$ & $(35.10 \pm 5.71)^{f}$ \\
\hline 1'-O-Methylphlojodicarpin (2) & $(15.04 \pm 1.26)^{\mathrm{g}}$ & $(6.02 \pm 1.56)^{\mathrm{e}}$ \\
\hline 1'-O-Methylvaginol (3) & $(11.99 \pm 2.14)^{\mathrm{f}}$ & $(6.42 \pm 2.07)^{\mathrm{e}}$ \\
\hline Murraol (4) & $2.83 \pm 0.46^{\mathrm{f}}$ & $(18.16 \pm 5.62)^{\mathrm{e}}$ \\
\hline Peroxymurraol (5) & $2.87 \pm 0.11^{\mathrm{g}}$ & $(5.78 \pm 2.98)$ \\
\hline Osthol (6) & $0.005 \pm 0.0002^{\mathrm{f}}$ & $(31.96 \pm 5.72)^{f}$ \\
\hline Osthenol (7) & $0.09 \pm 0.01^{\mathrm{g}}$ & $3.28 \pm 0.90^{\mathrm{g}}$ \\
\hline Auraptenol (8) & $0.77 \pm 0.11^{\mathrm{e}}$ & $(22.46 \pm 2.65)^{f}$ \\
\hline Peroxyauraptenol (9) & $0.41 \pm 0.06^{\mathrm{e}}$ & $7.83 \pm 1.17^{\mathrm{e}}$ \\
\hline Meranzin hydrate (10) & $7.31 \pm 1.62^{\mathrm{e}}$ & $4.21 \pm 1.41^{\mathrm{e}}$ \\
\hline Demethylauraptenol (11) & $0.54 \pm 0.05^{\mathrm{g}}$ & $4.36 \pm 1.67^{\mathrm{f}}$ \\
\hline Xanthotoxin (12) & $0.32 \pm 0.13^{\mathrm{e}}$ & $(14.81 \pm 6.03)$ \\
\hline Xanthotoxol (13) & $(24.54 \pm 2.47)^{\mathrm{g}}$ & $(42.94 \pm 4.29)^{\mathrm{g}}$ \\
\hline Imperatorin (14) & $0.07 \pm 0.02^{\mathrm{g}}$ & $(22.08 \pm 2.93)^{f}$ \\
\hline Bergapten (15) & $0.36 \pm 0.09^{\mathrm{e}}$ & $4.62 \pm 1.36^{\mathrm{e}}$ \\
\hline Isopimpinellin (16) & $2.75 \pm 0.26$ & $(8.97 \pm 2.28)^{\mathrm{e}}$ \\
\hline Cnidimol A (17) & $3.65 \pm 0.41^{\mathrm{g}}$ & $3.20 \pm 0.16^{\mathrm{g}}$ \\
\hline Diphenyleneiodonium $^{\mathrm{d}}$ & $0.55 \pm 0.20^{\mathrm{g}}$ & - \\
\hline Phenylmethylsulfonyl fluoride ${ }^{\mathrm{d}}$ & - & $34.4 \pm 5.5^{\mathrm{g}}$ \\
\hline
\end{tabular}

\footnotetext{
${ }^{\mathrm{a}}$ Results are presented as averages $\pm \operatorname{SEM}(n=4) ;{ }^{\mathrm{b}}$ Concentration necessary for $50 \%$ inhibition $\left(\mathrm{IC}_{50}\right)$. If $\mathrm{IC}_{50}$ value of compound was $<10 \mu \mathrm{g} / \mathrm{mL}$, it was displayed as $\mathrm{IC}_{50}[\mu \mathrm{g} / \mathrm{mL}] ;{ }^{\mathrm{c}}$ Percentage of inhibition (Inh \%) at $10 \mu \mathrm{g} / \mathrm{mL}$. If $\mathrm{IC}_{50}$ value of compound was $\geq 10 \mu \mathrm{g} / \mathrm{mL}$, it was shown as (Inh \%) at $10 \mu \mathrm{g} / \mathrm{mL}$; ${ }^{\mathrm{d}}$ Diphenyleneiodonium and phenylmethylsulfonyl were used as positive controls for superoxide anion generation and elastase release, respectively; ${ }^{\mathrm{e}} p<0.05$ compared with the control; ${ }^{\mathrm{f}} p<0.01$ compared with the control; ${ }^{\mathrm{g}} p<0.001$ compared with the control.
}

The effects on neutrophil pro-inflammatory responses of compounds isolated from the fruits of C. monnieri were evaluated by suppressing fMet-Leu-Phe/cytochalasin B (fMLP/CB)-induced superoxide anion $\left(\mathrm{O}_{2}{ }^{-}\right)$generation and elastase release by human neutrophils. The inhibitory activity data on neutrophil pro-inflammatory responses are summarized in Table 1. Diphenyleneiodonium and phenylmethylsulfonyl fluoride were used as positive controls for $\mathrm{O}_{2}{ }^{--}$generation and elastase release, respectively. From the results of our biological tests, the following conclusions can be drawn: (a) 3'-O-Methylmurraol (1), murraol (4), peroxymurraol (5), osthol (6), osthenol (7), auraptenol (8), 
peroxyauraptenol (9), meranzin hydrate (10), demethylauraptenol (11), xanthotoxin (12), imperatorin (14), bergapten (15), isopimpinellin (16), and cnidimol A (17) exhibited potent inhibition $\left(\mathrm{IC}_{50} \leq 7.31 \mu \mathrm{g} / \mathrm{mL}\right)$ of superoxide anion $\left(\mathrm{O}_{2}{ }^{-}\right)$generation by human neutrophils in response to fMLP/CB; (b) Osthenol (7), peroxyauraptenol (9), meranzin hydrate (10), demethylauraptenol (11), bergapten (15), and cnidimol A (17) exhibited potent inhibition $\left(\mathrm{IC}_{50} \leq 7.83 \mu \mathrm{g} / \mathrm{mL}\right.$ ) against fMLP-induced elastase release; (c) Among the furocoumarin analogues (12-16), imperatorin (14) (with a 9-isoprenyloxy group) exhibited more effective inhibition than its analogues, xanthotoxin (12) (with a 9-methoxy group), xanthotoxol (13) (with a 9-hydroxy group), bergapten (15) (with a 5-methoxy group), and isopimpinellin (16) (with 5,9-dimethoxy groups) against fMLP-induced $\mathrm{O}_{2}{ }^{--}$generation; (d) Among the coumarins with 7,8-disubstituents (1-11), osthol (6) and osthenol (7) with 8-isoprenyl group exhibited more effective inhibition than its analogues (1-5 and 8-11) against fMLP-induced $\mathrm{O}_{2}{ }^{--}$generation; (e) Osthol (6) was the most effective among these compounds, with $\mathrm{IC}_{50}$ value of $0.005 \pm 0.0002 \mu \mathrm{g} / \mathrm{mL}$ against fMLP-induced superoxide anion generation; (f) Cnidimol A (17) exhibited the most effective among the isolates, with $\mathrm{IC}_{50}$ value of $3.20 \pm 0.16 \mu \mathrm{g} / \mathrm{mL}$ against fMLP-induced elastase release

\section{Discussion}

Seventeen compounds, including three new coumarins 1-3, were isolated from the fruits of C. monnieri. Known compounds 5, 7, and $\mathbf{9}$ were obtained from this plant for the first time. The structures of these compounds were established on the basis of spectroscopic data. Further discovery of new coumarins from the genus Cnidium may not only provide more structure-activity data of coumarins, but may also contribute to enhancing our understanding of the taxonomy and evolution of the genus Cnidium.

Reactive oxygen species (ROS) (e.g., superoxide anion $\left(\mathrm{O}_{2}{ }^{\circ}\right)$, hydrogen peroxide) and granule proteases (e.g., elastase, cathepsin G) produced by human neutrophils contribute to the pathogenesis of inflammatory diseases. Inhibition of the inappropriate activation of neutrophils by drugs has been proposed as a way to ameliorate inflammatory diseases. Based on the results of our biological tests (Table 1), osthol (6), osthenol (7), and imperatorin (14) were the most effective among these compounds, with $\mathrm{IC}_{50}$ values of $0.005 \pm 0.0002,0.09 \pm 0.01$, and $0.07 \pm 0.02 \mu \mathrm{g} / \mathrm{mL}$, respectively, against fMLP-induced superoxide anion generation. Osthenol (7) and cnidimol A (17) exhibited the most effective among the isolates, with $\mathrm{IC}_{50}$ values of $3.28 \pm 0.90$ and $3.20 \pm 0.16 \mu \mathrm{g} / \mathrm{mL}$, respectively, against fMLP-induced elastase release. Compounds 6, 7, 14, and 17 had been tested for their cytotoxicity on the NIH3T3 cell, where $\mathbf{6}, \mathbf{7}, \mathbf{1 4}$, and 17 showed no significant activities with $\mathrm{ED}_{50}$ values $>50 \mu \mathrm{g} / \mathrm{mL}$. The above isolated compounds might support the traditional use of $C$. monnieri for the treatment of inflammatory processes. Thus, our study suggests $C$. monnieri and its isolates (especially 6, 7, 14, and 17) could be further developed as potential candidates for the treatment or prevention of various inflammatory diseases. 


\section{Experimental Section}

\subsection{Ethics Statement}

Blood was taken from healthy human donors (20-30 years old) by venipuncture, using a protocol (No. 102-1595A3) approved by the Institutional Review Board at Chang Gung Memorial Hospital (Taoyuan, Taiwan). All donors gave written consent. The Medical Ethics Committee of Chang Gung Memorial Hospital approved this consent procedure.

\subsection{General Experimental Procedures}

Melting points were determined on a Yanaco micro-melting point apparatus (Kyoto, Japan) and were uncorrected. Optical rotations were measured using a Jasco DIP-370 polarimeter (Tokyo, Japan) in $\mathrm{CHCl}_{3}$. Ultraviolet (UV) spectra were obtained on a Jasco UV-240 spectrophotometer (Tokyo, Japan). Infrared (IR) spectra (neat or $\mathrm{KBr}$ ) were recorded on a Perkin Elmer 2000 FT-IR spectrometer (Norwalk, CT, USA). Nuclear magnetic resonance (NMR) spectra, including correlation spectroscopy (COSY), nuclear Overhauser effect spectrometry (NOESY), heteronuclear multiple-bond correlation (HMBC), and heteronuclear single-quantum coherence (HSQC) experiments, were acquired using a Varian Inova 500 spectrometer operating at $500 \mathrm{MHz}\left({ }^{1} \mathrm{H}\right)$ and $125 \mathrm{MHz}\left({ }^{13} \mathrm{C}\right)$, respectively, with chemical shifts given in ppm $(\delta)$ using tetramethylsilane (TMS) as an internal standard. Electrospray ionisation (ESI) and high-resolution electrospray ionization (HRESI)-mass spectra were recorded on a Bruker APEX II or a VG Platform Electrospray ESI/MS mass spectrometer. Silica gel (70-230, 230-400 mesh, Merck) was used for column chromatography (CC). Silica gel 60 F-254 (Merck, Darmstadt, Germany) was used for thin-layer chromatography (TLC) and preparative thin-layer chromatography (PTLC).

\subsection{Plant Material}

The fruits of C. monnieri were collected from Yanpu, Pingtung County, Taiwan, in October 2010 and identified by Jih-Jung Chen. A voucher specimen (CM-201010) was deposited in the Department of Pharmacy, Tajen University, Pingtung, Taiwan.

\subsection{Extraction and Isolation}

The dried fruits $(4.0 \mathrm{~kg})$ of $C$. monnieri were extracted three times with $\mathrm{MeOH}(20 \mathrm{~L}$ each) for 3 days. The $\mathrm{MeOH}$ extracts were concentrated under reduced pressure at $35{ }^{\circ} \mathrm{C}$, and the residue (420 g) was partitioned between EtOAc and $\mathrm{H}_{2} \mathrm{O}$ (1:1). The EtOAc layer was concentrated to give a residue (fraction $\mathrm{A}, 145 \mathrm{~g}$ ). The water layer was further extracted with $n$ - $\mathrm{BuOH}$, and the $n$-BuOH-soluble part (fraction $\mathrm{B}, 132 \mathrm{~g}$ ) and the water-solubles (fraction $\mathrm{C}, 128 \mathrm{~g}$ ) were separated. Fraction A (110 g) was chromatographed on silica gel (70-230 mesh, $5.1 \mathrm{~kg})$, eluting with $n$-hexane, gradually increasing the polarity with acetone to give 12 fractions: A1 (5 L, $n$-hexane), A2 (4 L, $n$-hexane/acetone, 99:1), A3 (4 L, $n$-hexane/acetone, 95:1), A4 (5 L, $n$-hexane/acetone, 90:1), A5 (4 L, $n$-hexane/acetone, 80:1), A6 (4 L, $n$-hexane/acetone, 70:1), A7 (4 L, $n$-hexane/acetone, 50:1), A8 (6 L, $n$-hexane/acetone, 30:1), A9 (4 L, $n$-hexane/acetone, 10:1), A10 (5 L, $n$-hexane/acetone, 3:1), 
A11 (4 L, $n$-hexane/acetone, 1:1), A12 (5 L, acetone). Fraction A3 (9.8 g) was washed with MeOH and filtered to yield $6(325 \mathrm{mg})$ after recrystallization ( $n$-hexane/EtOAc, $2: 1)$. The filtrate was chromatographed on silica gel (230-400 mesh) eluting with $n$-hexane/EtOAc $(10: 1-0: 1)$ to give 11 fractions (each $750 \mathrm{~mL}, \mathrm{A3}-1-\mathrm{A} 3-11)$. Fraction A3-2 (95 mg) was purified by preparative TLC (silica gel, $n$-hexane/EtOAc, 9:5) to obtain $15(4.3 \mathrm{mg})\left(R_{f}=0.71\right)$. Fraction A3-4 (98 mg) was purified by preparative TLC (silica gel, $n$-hexane $\left./ \mathrm{CHCl}_{3}, 13: 7\right)$ to afford $12(3.8 \mathrm{mg})\left(R_{f}=0.32\right)$. Fraction A4 (9.3 g) was chromatographed further on silica gel (230-400 mesh, $455 \mathrm{~g})$ eluting with $n$-hexane/acetone (10:1-0:1) to give 12 fractions (each $800 \mathrm{~mL}, \mathrm{~A} 4-1-\mathrm{A} 4-12)$. Fraction A4-2 (585 mg) was purified by $\mathrm{CC}$ (silica gel, hexane/acetone, 8:1-0:1) to afford 8 subfractions (each $250 \mathrm{~mL}$, A4-2-1-A4-2-8). Fraction A4-2-3 (82 $\mathrm{mg})$ was purified by preparative TLC (silica gel, $n$-hexane/EtOAc, 3:1) to obtain $6(3.8 \mathrm{mg})\left(R_{f}=0.50\right)$ and $14(4.1 \mathrm{mg})\left(R_{f}=0.38\right)$. Fraction A4-3 $\left(136 \mathrm{mg}\right.$ ) was purified by preparative TLC (silica gel, $\left.\mathrm{CHCl}_{3} / \mathrm{EtOAc}, 30: 1\right)$ to afford $\mathbf{1 5}(3.2 \mathrm{mg}$ ) $\left(R_{f}=0.66\right)$ and $16(3.5 \mathrm{mg})\left(R_{f}=0.49\right)$. Fraction A4-5 $(125 \mathrm{mg})$ was purified by preparative TLC (silica gel, $\mathrm{CH}_{2} \mathrm{Cl}_{2} /$ acetone, 50:1) to yield $9(3.5 \mathrm{mg})\left(R_{f}=0.22\right)$. Fraction A5 (8.5 g) was chromatographed further on silica gel (230-400 mesh, $445 \mathrm{~g})$ eluting with $n$-hexane/EtOAc (10:1-0:1) to give 10 fractions (each $850 \mathrm{~mL}, \mathrm{~A} 5-1-\mathrm{A} 5-10)$. Fraction A5-2 (88 $\mathrm{mg}$ ) was purified by preparative TLC (silica gel, $n-\mathrm{CHCl}_{3} /$ EtOAc, 20:1) to obtain $7(3.7 \mathrm{mg})\left(R_{f}=0.43\right)$. Fraction A5-3 (75 mg) was purified by preparative TLC (silica gel, $n$-hexane/EtOAc, 11:7) to obtain $2(3.6 \mathrm{mg})\left(R_{f}=0.48\right)$. Fraction A5-4 (90 mg) was purified by preparative TLC (silica gel, $n$-hexane/EtOAc, 11:9) to give 8 (5.2 $\mathrm{mg})\left(R_{f}=0.31\right)$. Fraction A5-5 $(80 \mathrm{mg})$ was purified by preparative TLC (silica gel, $n$-hexane/EtOAc, $1: 1)$ to afford $5(3.7 \mathrm{mg})\left(R_{f}=0.36\right)$. Fraction A5-6 (105 $\left.\mathrm{mg}\right)$ was purified by preparative TLC (silica gel, $\mathrm{CH}_{2} \mathrm{Cl}_{2} /$ EtOAc, $\left.2: 1\right)$ to yield $13(5.5 \mathrm{mg})\left(R_{f}=0.70\right)$. Fraction A6 $(8.2 \mathrm{~g})$ was chromatographed further on silica gel (230-400 mesh, $430 \mathrm{~g})$ eluting with $n$-hexane/acetone (6:1-0:1) to give 8 fractions (each $850 \mathrm{~mL}$, A6-1-A6-8). Fraction A6-2 (78 mg) was purified by preparative TLC (silica gel, $\left.\mathrm{CH}_{2} \mathrm{Cl}_{2} / \mathrm{EtOAc}, 2: 1\right)$ to obtain $3(3.4 \mathrm{mg})\left(R_{f}=0.55\right)$. Fraction A6-3 (83 mg) was purified by preparative TLC (silica gel, $\mathrm{CH}_{2} \mathrm{Cl}_{2} / \mathrm{EtOAc}, 1: 1$ ) to obtain 1 (3.9 $\mathrm{mg}$ ) $\left(R_{f}=0.83\right)$. Fraction A8 $(9.3 \mathrm{~g})$ was chromatographed further on silica gel (230-400 mesh, $\left.460 \mathrm{~g}\right)$ eluting with $n$-hexane/EtOAc (4:1-0:1) to give 9 fractions (each $900 \mathrm{~mL}, \mathrm{~A} 8-1-\mathrm{A} 8-9)$. Fraction A8-2 (115 mg) was purified by preparative TLC (silica gel, $\mathrm{CH}_{2} \mathrm{Cl}_{2} /$ EtOAc, 1:1) to afford 4 (4.3 $\mathrm{mg}$ ) $\left(R_{f}=0.62\right)$. Fraction A8-3 (86 mg) was purified by preparative TLC (silica gel, $\mathrm{CH}_{2} \mathrm{Cl}_{2} / \mathrm{MeOH}, 30: 1$ ) to yield $11(3.9 \mathrm{mg})\left(R_{f}=0.43\right)$. Fraction A8-4 $(86 \mathrm{mg})$ was purified by preparative TLC (silica gel, $\mathrm{CH}_{2} \mathrm{Cl}_{2} /$ EtOAc, $\left.1: 1\right)$ to obtain $17(3.2 \mathrm{mg})\left(R_{f}=0.61\right)$. Fraction A8-5 (102 mg) was purified by preparative TLC (silica gel, $\mathrm{CH}_{2} \mathrm{Cl}_{2} /$ EtOAc, $\left.1: 1\right)$ to obtain $10(3.8 \mathrm{mg})\left(R_{f}=0.19\right)$.

\subsubsection{3'-O-Methylmurraol (1)}

Colorless prisms $(\mathrm{MeOH})$, m.p. $129-131{ }^{\circ} \mathrm{C} . \mathrm{UV}(\mathrm{MeOH}): \lambda_{\max }(\log \varepsilon)=213$ (4.24), 247 (3.76), 257 (3.77), 319 (4.12) nm. IR (KBr): $v_{\max }=1727(\mathrm{C}=\mathrm{O}) \mathrm{cm}^{-1} .{ }^{1} \mathrm{H}-\mathrm{NMR}\left(\mathrm{CDCl}_{3}, 500 \mathrm{MHz}\right): \delta=1.42$ $(6 \mathrm{H}, \mathrm{s}, \mathrm{H}-4$ ' and H-5'), 3.28 (3H, s, OMe-3'), 3.95 (3H, s, OMe-7), $6.27(1 \mathrm{H}, \mathrm{d}, J=9.5 \mathrm{~Hz}, \mathrm{H}-3)$, $6.79\left(1 \mathrm{H}, \mathrm{d}, J=16.0 \mathrm{~Hz}, \mathrm{H}-2^{\prime}\right), 6.83\left(1 \mathrm{H}, \mathrm{d}, J=16.0 \mathrm{~Hz}, \mathrm{H}-1^{\prime}\right), 6.88(1 \mathrm{H}, \mathrm{d}, J=9.0 \mathrm{~Hz}, \mathrm{H}-6)$, $7.31(1 \mathrm{H}, \mathrm{d}, J=9.0 \mathrm{~Hz}, \mathrm{H}-5), 7.63(1 \mathrm{H}, \mathrm{d}, J=9.5 \mathrm{~Hz}, \mathrm{H}-4) .{ }^{13} \mathrm{C}-\mathrm{NMR}\left(\mathrm{CDCl}_{3}, 125 \mathrm{MHz}\right): \delta=25.9$ (C-4'), 25.9 (C-5'), 50.7 (OMe-3'), 56.1 (OMe-7), 107.6 (C-6), 113.0 (C-4a), 113.2 (C-3), 113.8 (C-8), 
117.1 (C-1'), 127.0 (C-5), 142.4 (C-2'), 143.8 (C-4), 152.6 (C-8a), 160.3 (C-7), 160.9 (C-2). ESI-MS: $m / z=297[\mathrm{M}+\mathrm{Na}]^{+}$. HR-ESI-MS: $m / z=297.1105[\mathrm{M}+\mathrm{Na}]^{+}$(calcd for $\mathrm{C}_{16} \mathrm{H}_{18} \mathrm{O}_{4} \mathrm{Na}$ : 297.1103).

\subsection{2. rel-(1'S,2'S)-1'-O-Methylphlojodicarpin (2)}

Colorless needles $\left(\mathrm{CH}_{2} \mathrm{Cl}_{2}-\mathrm{MeOH}\right)$; m.p. $141-143{ }^{\circ} \mathrm{C} .[\alpha]_{\mathrm{D}}{ }^{25}:-28.4$ (c 0.14, $\left.\mathrm{CHCl}_{3}\right)$. UV (MeOH): $\lambda_{\max }(\log \varepsilon)=219$ (4.17), 244 (3.95), 253 (sh, 3.85), $318(4.15) \mathrm{nm}$. IR (neat): $v_{\max } 1733(\mathrm{C}=\mathrm{O}) \mathrm{cm}^{-1}$. ${ }^{1} \mathrm{H}-\mathrm{NMR}\left(\mathrm{CDCl}_{3}, 500 \mathrm{MHz}\right): \delta=1.08\left(3 \mathrm{H}, \mathrm{s}, \mathrm{H}-5\right.$ ') $1.27\left(3 \mathrm{H}, \mathrm{s}, \mathrm{H}-4{ }^{\prime}\right), 3.48\left(3 \mathrm{H}, \mathrm{s}, \mathrm{OMe}-1^{\prime}\right), 3.81(1 \mathrm{H}$, d, $\left.J=7.0 \mathrm{~Hz}, \mathrm{H}-2^{\prime}\right), 3.94(3 \mathrm{H}, \mathrm{s}, \mathrm{OMe}-7), 4.84\left(1 \mathrm{H}, \mathrm{d}, J=7.0 \mathrm{~Hz}, \mathrm{H}-1^{\prime}\right), 6.27(1 \mathrm{H}, \mathrm{d}, J=9.5 \mathrm{~Hz}, \mathrm{H}-3)$, $6.91(1 \mathrm{H}, \mathrm{d}, J=8.5 \mathrm{~Hz}, \mathrm{H}-6), 7.44(1 \mathrm{H}, \mathrm{d}, J=8.5 \mathrm{~Hz}, \mathrm{H}-5), 7.64(1 \mathrm{H}, \mathrm{d}, J=9.5 \mathrm{~Hz}, \mathrm{H}-4)$. ${ }^{13} \mathrm{C}-\mathrm{NMR}\left(\mathrm{CDCl}_{3}, 125 \mathrm{MHz}\right): \delta=19.4\left(\mathrm{C}-5^{\prime}\right), 24.7\left(\mathrm{C}-4^{\prime}\right), 56.8\left(\mathrm{C}-33^{\prime}\right), 56.3(\mathrm{OMe}-7), 57.6\left(\mathrm{OMe}-1^{\prime}\right)$, 65.6 (C-2'), 75.1 (C-1'), 108.0 (C-6), 113.1 (C-4a), 113.5 (C-3), 114.6 (C-8), 129.2 (C-5), 143.5 (C-4), 153.3 (C-8a), $160.2(\mathrm{C}-2), 160.7$ (C-7). ESI-MS: $m / z=313[\mathrm{M}+\mathrm{Na}]^{+}$. HR-ESI-MS: $m / z=313.1050$ $[\mathrm{M}+\mathrm{Na}]^{+}$(calcd for $\mathrm{C}_{16} \mathrm{H}_{18} \mathrm{O}_{5} \mathrm{Na}: 313.1052$ ).

\subsection{3. (1'S,2'S)-1'-O-Methylvaginol (3)}

Colorless prisms $(\mathrm{MeOH})$, m.p. $166-168{ }^{\circ} \mathrm{C} . \mathrm{UV}(\mathrm{MeOH}): \lambda_{\max }(\log \varepsilon)=214$ (4.31), $245(\mathrm{sh}$, 3.86), 256 (sh, 3.80), 287 (sh, 3.91), $322(4.18) \mathrm{nm}$. IR (KBr): $v_{\max }=3454(\mathrm{OH}), 1727(\mathrm{C}=\mathrm{O}) \mathrm{cm}^{-1}$. ${ }^{1} \mathrm{H}-\mathrm{NMR}\left(\mathrm{CDCl}_{3}, 400 \mathrm{MHz}\right): \delta=1.26\left(3 \mathrm{H}, \mathrm{s}, \mathrm{H}-4^{\prime}\right), 1.33\left(3 \mathrm{H}, \mathrm{s}, \mathrm{H}-5^{\prime}\right), 1.72\left(1 \mathrm{H}\right.$, br s, $\mathrm{D}_{2} \mathrm{O}$ exchangeable, OH-3'), $3.65\left(3 \mathrm{H}, \mathrm{s}, \mathrm{OMe}-1^{\prime}\right), 4.53\left(1 \mathrm{H}, \mathrm{d}, J=3.0 \mathrm{~Hz}, \mathrm{H}-2^{\prime}\right), 5.23(1 \mathrm{H}, \mathrm{d}, J=3.0 \mathrm{~Hz}$, H-1'), 6.25 (1H, d, $J=9.5 \mathrm{~Hz}, \mathrm{H}-3), 6.82(1 \mathrm{H}, \mathrm{d}, J=8.5 \mathrm{~Hz}, \mathrm{H}-6), 7.39$ (1H, d, $J=8.5 \mathrm{~Hz}, \mathrm{H}-5), 7.65$ $(1 \mathrm{H}, \mathrm{d}, J=9.5 \mathrm{~Hz}, \mathrm{H}-4) .{ }^{13} \mathrm{C}-\mathrm{NMR}\left(\mathrm{CDCl}_{3}, 100 \mathrm{MHz}\right): \delta=24.9\left(\mathrm{C}-4\right.$ '), $25.3\left(\mathrm{C}-5^{\prime}\right), 57.8\left(\mathrm{OMe}-1^{\prime}\right)$, 79.4 (C-1'), 96.3 (C-2'), 107.5 (C-6), 112.6 (C-3), 113.2 (C-4a), 114.2 (C-8), 131.2 (C-5), 143.9 (C-4), 152.3 (C-8a), 160.5 (C-2), $164.6(\mathrm{C}-7)$. ESI-MS: $m / z=299[\mathrm{M}+\mathrm{Na}]^{+}$. HR-ESI-MS: $m / z=299.0892$ $[\mathrm{M}+\mathrm{Na}]^{+}$(calcd for $\mathrm{C}_{15} \mathrm{H}_{16} \mathrm{O}_{5} \mathrm{Na}: 299.0895$ ).

\subsubsection{Supplementary Files}

ESI-MS, HR-ESI-MS, ${ }^{1} \mathrm{H}-\mathrm{NMR}$, and ${ }^{13} \mathrm{C}-\mathrm{NMR}$ spectra of three new compounds (1-3) are available as Supplementary Information.

\subsection{Biological Assay}

The effect of the isolated compounds on neutrophil pro-inflammatory response was evaluated by monitoring the inhibition of superoxide anion generation and elastase release in $\mathrm{MLP} / \mathrm{CB}$-activated human neutrophils in a concentration-dependent manner. The purity of the tested compounds was $>98 \%$ as identified by NMR and MS.

\subsubsection{Preparation of Human Neutrophils}

Human neutrophils from venous blood of healthy, adult volunteers (20-28 years old) were isolated using a standard method of dextran sedimentation prior to centrifugation in a Ficoll Hypaque gradient and hypotonic lysis of erythrocytes [23]. Purified neutrophils containing $>98 \%$ viable cells, as 
determined by the trypan blue exclusion method [24], were re-suspended in a calcium $\left(\mathrm{Ca}^{2+}\right)$-free HBSS buffer at $\mathrm{pH} 7.4$ and were maintained at $4{ }^{\circ} \mathrm{C}$ prior to use.

\subsubsection{Measurement of Superoxide Anion Generation}

The assay for measurement of superoxide anion generation was based on the SOD-inhibitable reduction of ferricytochrome $c[25,26]$. In brief, after supplementation with $0.5 \mathrm{mg} / \mathrm{mL}$ ferricytochrome $c$ and $1 \mathrm{mM} \mathrm{Ca}^{2+}$, neutrophils $\left(6 \times 10^{5} / \mathrm{mL}\right)$ were equilibrated at $37{ }^{\circ} \mathrm{C}$ for 2 min and incubated with different concentrations $(10-0.01 \mu \mathrm{g} / \mathrm{mL}$ ) of compounds or DMSO (as control) for 5 min. Cells were incubated with cytochalasin B $(1 \mu \mathrm{g} / \mathrm{mL})$ for $3 \mathrm{~min}$ prior to the activation with $100 \mathrm{nM}$ formyl-L-methionyl-L-leucyl-L-phenylalanine for $10 \mathrm{~min}$. Changes in absorbance with the reduction of ferricytochrome $c$ at $550 \mathrm{~nm}$ were continuously monitored in a double-beam, six-cell positioner spectrophotometer with constant stirring (Hitachi U-3010, Tokyo, Japan). Calculations were based on differences in the reactions with and without SOD $(100 \mathrm{U} / \mathrm{mL})$ divided by the extinction coefficient for the reduction of ferricytochrome $c(\varepsilon=21.1 / \mathrm{mM} / 10 \mathrm{~mm})$.

\subsubsection{Measurement of Elastase Release}

Degranulation of azurophilic granules was determined by measuring elastase release as described previously $[25,26]$. Experiments were performed using MeO-Suc-Ala-Ala-Pro-Val- $p$-nitroanilide as the elastase substrate. Briefly, after supplementation with MeO-Suc-Ala-Ala-Pro-Val- $p$-nitroanilide $(100 \mu \mathrm{M})$, neutrophils $\left(6 \times 10^{5} / \mathrm{mL}\right)$ were equilibrated at $37{ }^{\circ} \mathrm{C}$ for $2 \mathrm{~min}$ and incubated with compounds for $5 \mathrm{~min}$. Cells were stimulated with fMLP $(100 \mathrm{nM}) / \mathrm{CB}(0.5 \mu \mathrm{g} / \mathrm{mL})$, and changes in absorbance at $405 \mathrm{~nm}$ were monitored continuously in order to assay elastase release. The results were expressed as the percent of elastase release in the fMLP/CB-activated, drug-free control system.

\subsubsection{Statistical Analysis}

Results are expressed as the mean \pm SEM, and comparisons were made using Student's $t$-test. A probability of 0.05 or less was considered significant. The software SigmaPlot was used for the statistical analysis.

\section{Conclusions}

Seventeen compounds, including three new coumarins (1-3), were isolated from the fruits of C. monnieri. The structures of these compounds were established on the basis of spectroscopic data. Reactive oxygen species (ROS) (e.g., superoxide anion $\left(\mathrm{O}_{2}{ }^{-}\right)$, hydrogen peroxide) and granule proteases (e.g., elastase, cathepsin $\mathrm{G}$ ) produced by human neutrophils contribute to the pathogenesis of inflammatory diseases. The effects on neutrophil pro-inflammatory responses of isolates were evaluated by suppressing fMLP/CB-induced $\mathrm{O}_{2}{ }^{--}$generation and elastase release by human neutrophils. The results of anti-inflammatory experiments indicate that compounds 1, 4-12, and 14-17 can significantly inhibit fMLP-induced $\mathrm{O}_{2}{ }^{--}$generation and/or elastase release. Osthol (6) and cnidimol A (17) were the most effective among the isolated compounds, with $\mathrm{IC}_{50}$ values of $0.005 \pm 0.0002$ and $3.20 \pm 0.16 \mu \mathrm{g} / \mathrm{mL}$, respectively, against fMLP-induced $\mathrm{O}_{2}{ }^{--}$generation and elastase release. Our study 
suggests $C$. monnieri and its isolates (especially 6, 7, 14, and 17) could be further developed as potential candidates for the treatment or prevention of various inflammatory diseases.

\section{Acknowledgments}

This research was supported by grants from the National Science Council of the Republic of China (No. NSC 98-2320-B-127-001-MY3 and NSC 101-2320-B-127-001-MY3), awarded to J.-J. Chen.

\section{Author Contributions}

Jih-Jung Chen designed the research; Tzong-Huei Lee, Yuan-Chih Chen, and Tsong-Long Hwang performed the experiments; Jih-Jung Chen, Chih-Wen Shu, Ping-Jyun Sung, Yun-Ping Lim, and Wen-Lung Kuo contributed to the analysis of the data; Jih-Jung Chen wrote the paper.

\section{Conflicts of Interest}

The authors declare no conflict of interest.

\section{References}

1. Chinese Pharmacopoeia Commission. Pharmacopoeia of the People's Republic of China; China Medical Science and Technology Press: Beijing, China, 2010; Volume 1, pp. 295-296.

2. Zhu, Y.P. Chinese Material Medica. Chemistry, Pharmacology and Applications; Harwood Academic Publishers: Amsterdam, The Netherlands, 1998; pp. 624-625.

3. Baba, K.; Kawanishi, H.; Taniguchi, M.; Kozawa, M. Chromones from Cnidium monnieri. Phytochemistry 1992, 31, 1367-1370.

4. Chen, Y.; Fan, G.; Zhang, Q.; Wu, H.; Wu, Y. Fingerprint analysis of the fruits of Cnidium monnieri extract by high-performance liquid chromatography-diode array detection-electrospray ionization tandem mass spectrometry. J. Pharm. Biomed. Anal. 2007, 43, 926-936.

5. Basnet, P.; Yasuda, I.; Kumagai, N.; Tohda, C.; Nojima, H.; Kuraishi, Y.; Komatsu, K. Inhibition of itch-scratch response by fruits of Cnidium monnieri in mice. Biol. Pharm. Bull. 2001, 24, 1012-1015.

6. Cai, J.N.; Basnet, P.; Wang, Z.T.; Komatsu, K.; Xu, L.S.; Tani, T. Coumarins from the fruits of Cnidium monnieri. J. Nat. Prod. 2000, 63, 485-488.

7. Yang, L.L.; Wang, M.C.; Chen, L.G.; Wang, C.C. Cytotoxic activity of coumarins from the fruits of Cnidium monnieri on leukemia cell lines. Planta Med. 2003, 69, 1091-1095.

8. Dien, P.H.; Nhan, N.T.; Le Thuy, H.T.; Quang, D.N. Main constituents from the seeds of Vietnamese Cnidium monnieri and cytotoxic activity. Nat. Prod. Res. 2012, 26, 2107-2111.

9. Honda, G.; Tabata, M.; Baba, K.; Kozawa, M. On the antidermatophytic constituents and the original plants of the traditional Chinese drug "She chuang zi". Shoyakugaku Zasshi 1984, 38, 221-226.

10. Yahara, S.; Sugimura, C.; Nohara, T.; Niiho, Y.; Nakajima, Y.; Ito, H. Studies on the constituents of Cnidii monnieri Fructus. Shoyakugaku Zasshi 1993, 47, 74-78.

11. Kitajima, J.; Aoki, Y.; Ishikawa, T.; Tanaka, Y. Monoterpenoid glucosides of Cnidium monnieri fruit. Chem. Pharm. Bull. 1999, 47, 639-642. 
12. Ito, C.; Furukawa, H. Constituents of Murraya exotica L. Structure elucidation of new coumarins. Chem. Pharm. Bull. 1987, 35, 4277-4285.

13. Ito, C.; Furukawa, H. Two new coumarins from Murraya plants. Chem. Pharm. Bull. 1989, 37, 819-820.

14. Gantimur, D.; Semenov, A.A. Coumarins from Phlojodicarpus sibiricus. Chem. Nat. Comp. 1981, $17,41-43$.

15. Zhao, J.; Zhou, M.; Liu, Y.; Zhang, G.; Luo, Y. Chromones and coumarins from the dried fructus of Cnidium monnieri. Fitoterapia 2011, 82, 767-771.

16. Zou, Y.; Lobera, M.; Snider, B.B. Synthesis of 2,3-dihydro-3-hydroxy-2-hydroxylalkylbenzofurans from epoxy aldehydes. One-step syntheses of brosimacutin G, vaginidiol, vaginol, smyrindiol, xanthoarnol, and avicenol A. Biomimetic syntheses of angelicin and psoralen. J. Org. Chem. 2005, 70, 1761-1770.

17. Razdan, T.K.; Qadri, B.; Harkar, S.; Waight, E.S. Chromones and coumarins from Skimmia laureola. Phytochemistry 1987, 26, 2063-2069.

18. Sasaki, H.; Taguchi, H.; Endo, T.; Yosioka, I. The constituents of Glehnia littoralis Fr. Schmidt et Miq. Structure of a new coumarin glycoside, osthenol 7-O- $\beta$-gentiobioside. Chem. Pharm. Bull. 1980, 28, 1847-1852.

19. Irnai, F.; Kinoshita, T.; Sankawa, U. Constituents of the leaves of Murraya paniculata collected in Taiwan. Chem. Pharm. Bull. 1989, 37, 358-362.

20. Barik, B.R.; Dey, A.K.; Das, P.C.; Chatterjee, A.; Shoolery, J.N. Coumarins of Murraya exotica. Absolute configuration of auraptenol. Phytochemistry 1983, 22, 792-794.

21. Stevensona, P.C.; Simmondsa, M.S.J.; Yulea, M.A.; Veitcha, N.C.; Kitea, G.C.; Irwinb, D.; Leggb, M. Insect antifeedant furanocoumarins from Tetradium daniellii. Phytochemistry 2003, $63,41-46$.

22. Baba, K.; Hamasaki, F.; Tabata, Y.; Kozawa, M.; Honda, G.; Tabata, M. Chemical studies on Chinese crude drug "She Chuang Zi”. Shoyakugaku Zasshi 1985, 39, 282-290.

23. Boyum, A. Isolation of mononuclear cells and granulocytes from human blood. Isolation of monuclear cells by one centrifugation, and of granulocytes by combining centrifugation and sedimentation at 1 g. Scand. J. Clin. Lab. Investig. 1968, 97, 77-89.

24. Jauregui, H.O.; Hayner, N.T.; Driscoll, J.L.; Williams-Holland, R.; Lipsky, M.H.; Galletti, P.M. Trypan blue dye uptake and lactate dehydrogenase in adult rat hepatocytes-freshly isolated cells, cell suspensions, and primary monolayer cultures. In Vitro 1981, 17, 1100-1110.

25. Hwang, T.L.; Leu, Y.L.; Kao, S.H.; Tang, M.C.; Chang, H.L. Viscolin, a new chalcone from Viscum coloratum, inhibits human neutrophil superoxide anion and elastase release via a cAMP-dependent pathway. Free Radic. Biol. Med. 2006, 41, 1433-1441.

26. Chen, J.J.; Ting, C.W.; Wu, Y.C.; Hwang, T.L.; Cheng, M.J.; Sung, P.J.; Wang, T.C.; Chen, J.F. New labdane-type diterpenoids and anti-inflammatory constituents from Hedychium coronarium. Int. J. Mol. Sci. 2013, 14, 13063-13077.

(C) 2014 by the authors; licensee MDPI, Basel, Switzerland. This article is an open access article distributed under the terms and conditions of the Creative Commons Attribution license (http://creativecommons.org/licenses/by/3.0/). 